\title{
The Effect of IFRS Adoption on Foreign Direct Investment in Africa
}

\author{
Alhassan Musah ${ }^{\mathrm{a},{ }^{*}}$, Eunice Adjei ${ }^{\mathrm{b}}$ and Ibrahim Anyass Ahmed ${ }^{\mathrm{c}}$ \\ ${ }^{a}$ School of Business, Academic City College, alaye88@gmail.com, Ghana \\ b School of Business, Academic City College, Eunice.adjei@acity.edu.gh, Ghana \\ ${ }^{\mathrm{c}}$ School of Business, Academic City College, mamastughosh@gmail.com, Ghana
}

\begin{abstract}
Adoption of International Financial Reporting Standards (IFRS) is supposed to help enhance comparability of financial statement, improve the quality of financial reporting and accounting information of businesses in a country. This is expected to help improve Foreign Direct Investment (FDI) in the adopting countries. This study examined the effect of IFRS adoption on FDI inflows in Africa. Unlike previous studies that sample both adopting and non-adopting countries, this study sampled only Africa countries that have adopted IFRS to determine whether the adoption has improved FDI inflows. To achieve this objective, 20 African countries that have adopted IFRS were sampled covering a period 1980 to 2015. Data was sourced from The World Bank financial and Economic Data. Control variables such as GDP growth, openness of the economy, government debt and population growth were included in the model. The correlation and regression analysis showed that IFRS adoption has a positive and significant influence on FDI inflows in Africa. On the other hand, open economy, government debt and population growth had a positive and significant association with FDI. Overall, the results show that African countries that want to improve FDI inflows must improve the quality of their reporting environment by adopting IFRS.
\end{abstract}

Keywords: IFRS, Foreign Direct Investment, Macroeconomic variables, Africa.

*Corresponding author. E-mail: alaye88@gmail.com 


\section{Introduction}

Globalization has increased the need for uniform accounting and financial reporting standards that will allow capital flows across the globe (Emeni, 2014). The need for global accounting standard that is uniform stems from the fact that harmonization of financial reporting will encourage uniformity in financial reporting, it will improve consistency of accounting information thereby enhancing comparability and reliability of accounting information (Daske, 2006). The adoption of International Financial Reporting Standards across the globe was also one of the measures to reduce the widespread corporate scandals which had their root in fraudulent financial reporting (Emeni, 2014). Studies have also shown that differences in national accounting standards have been a stumbling block on cross-border investment (Tweedie \& Seidenstein, 2004; Ahearme et al., 2004). These and other reasons accounted for the widespread adoption of IFRS by countries across the globe. The European Union in 2005 mandated all public firms in the EU zone to adopt IFRS. In the African context, several countries have adopted IFRS especially the Anglophone countries. According to report from the International Accounting Standards Board (IASB) several francophone African countries are either adopting or converging with IFRS. It is estimated that about 34 African countries have either adopted or are in advance stages of adopting IFRS.

In response to these widespread adoptions of IFRS adoption, several studies have been conducted to examine the consequence of IFRS adoption which has mostly focused on the individual firm level (Chen et al. 2012; Barth et al. 2008; Ahmed et al. 2013). This notwithstanding, recent studies have sort to examine the macroeconomic effect of IFRS adoption on countries with specific interest in cross-border investment consequence of IFRS adoption (Owusu et al. (2017a). These studies suggest that IFRS adoption improves the competitiveness and attractiveness of the adopting country in terms of cross-border investment which enhance FDI inflows into these countries (Zhu, 2014; Marquez-Ramos, 2011; Chen, Ding \& Xu, 2014; Gordon et al. 2012; Louis \& Urcan, 2014). The main argument of these studies is the fact that differences in National Accounting Standards is a major source of information asymmetry from the perspective of foreign investors which inhibit the inflow of FDIs. The adoption of IFRS is supposed to reduce or eliminate all these information asymmetries thereby enhancing cross-border investment on the form of FDI.

Several studies have examined the determinants of FDI inflows but have mainly focused on macroeconomic determinants of FDI inflows (Mottaleb \& Kalirajan, 2010; Asiedu, 2006; Chakrabarti, 2007; Busse \&Hefeker, 2007). Owusu et al. (2017b) argue that despite the widespread studies on determinants of FDI, there is no conclusive evidence on the variables are determine the level of FDI inflows. The adoption of IFRS is expected to improve FDI inflows in the adopting countries (Emeni, 2014; Ramanna \& Sletten, 2009).

Several studies have been conducted to examine the impact of IFRS adoption on FDI inflows (Chen et al. 2011; Ramanna \& Sletten, 2009; Zhu, 2014; MarquezRamos, 2011; Chen,Ding \& Xu, 2014, 2014; Gordon et al. 2012; Louis \& Urcan, 2014). Most of these studies have focused on developed countries with little on developing countries. Some few studies in the recent past have begun the focus on the impact of IFRS adoption on FDI in developing countries but with inconclusive evidence (Owusu et al. 2017a); Owusu et al. 2017b; Emeeni, 2014). For instance, Owusu et al. (2017a) examined the effect of IFRS adoption, institutional quality and FDI inflows based on a sample of developing countries across the globe and concluded that the adoption of IFRS on its own does not improve FDI inflows in developing countries but developing countries with better institutional quality who adopt IFRS improve FDI inflows. Owusu et al. (2017b) conducted a study on does IFRS adoption matter for FDI in developing countries and found that IFRS adoption alone does not improve FDI inflows. Emeni (2014) examined the effect of IFRS adoption on FDI inflows in Africa but found that IFRS adoption has a positive but statistically insignificant association with FDI inflows. Other studies in different countries reported a positive and significant association between IFRS adoption and FDI inflows (Gorden et al. 2012; Marquez-Ramos, 2011; Zhu, 2014). The study however sampled African countries that have adopted and those that have not adopted IFRS. In addition to the above, some studies have suggested that IFRS adoption in developing countries will have more significant impact on FDI compared to developed countries (Gordon et al. 2012; Ismail et al. 2013). This study focuses on only African countries that have adopted IFRS to determine the Impact IFRS adoption has had on their FDI inflows. Besides previous studies on the subject matter on developing countries has produced mixed results which call for more studies to establish the real effect of IFRS adoption on FDI. 
Moreover, most of these studies have used the monetary amount of FDI or the natural logarithm of FDI inflows to represent FDI. This study uses FDI as a percentage of GDP which improves the effect of inflation and other effects which the ratio eliminates. This study therefore examines IFRS adoption and its impact on FDI inflows using a sample of African countries that have adopted and implemented IFRS.

\section{Contribution of the study}

The study makes significant contribution to literature on the area of IFRS adoption and its consequence on the macro economy contrary to majority of studies that have focused on firm level analysis of the subject matter.

The study also makes significant contribution in the area of IFRS adoption and FDI in developing countries especially Africa since previous studies have produced inconclusive results (Owusu et al. 2017a); Owusu et al. 2017b; Emeeni, 2014).

The result of the study is useful for African countries who are yet to adopt IFRS or are in the process of adopting IFRS to enhance their competitiveness and to attract FDI inflows as it will help them affirm their decision or otherwise.

The rest of the paper presents the theoretical review, the empirical review, the methodology, analysis and discussion of findings as well as conclusions drawn.

\section{Theoretical Review}

Previous studies have used several theories including Dunning Eclectic Paradigm, Theory of Transaction Cost Economics, and Internationalization theory, Hymer's Firm Specific Advantages Theory, Gravity Model etc to explain determinants or crossborder inflow of capital or investment among countries. The common them among these theories is the fact the there is an assumption of market imperfection which requires cross-border investment flows. Dunning (1979) argues that the imperfections in markets compels entities to exploit foreign market as alternative to local market failures. Hymer (1970) in this context argue that firms will always exploit opportunities in foreign markets to capitalize their advantage over firms in those markets.

Teece (1986) argue that the theory of Transaction Cost Economics cost minimization is a major gaol of every entity. The theory is based on the assumption that an entity choice of a business transaction depends largely on cost consideration (Coase, 1937). In the same vein, the Transaction Cost Economics shows that businesses will locate their production system in location that gives them cost advantage (Owusu et al. 2017b). This means that multinational will locate their businesses in countries where cost of production will be relatively low.

The Internationalization theory similar to the Transaction Cost Economics explains factors that push firms to expand their operations to other jurisdictions (Buckley \& Casson, 1976). The theory also assumes that firms will only go beyond their jurisdiction if the new market provides opportunities in terms of low transaction cost of engagement (Owusu et al. 2017b). The theory further posits that firms will like to expand to foreign market through the use of production facility rather than through externalization especially when it has competitive advantage over local market in the chosen market in a particular area. In summary it can be concluded that both the Transaction Cost Economics and the Internationalization theory sees cost advantage as the biggest motivation for business chosen a particular foreign market or doing business in their local market. However, other factors may influence firm's choice of a foreign market which the Eclectic paradigm seeks to address. According to Owusu et al. (2017b), the Eclectic theory is considered more comprehensive in terms of explaining determinants of FDI as compared to the other theories in recent times.

The Eclectic theory presents a combination of country-specific as well as firm-specific variables that explains cross-border investment decisions (Dunning, 1976). The Eclectic theory is a combination of location advantage (L), Internationalization advantage (I) and Ownership Specific advantage to explain the determinants of FDI (Owusu et al. 2017b). The paradigm argues that FDI occurs when there is ownership advantage and location advantage as well as Internationalization advantage in production process in the host country (Frenkel et al. 2004). Ownership specific advantage in this context includes technological superiority, economics of scale and scope etc ((Forssbæck \& Oxelheim, 2008). According to Owusu et al. (2017b) the adoption of IFRS reduces informational disadvantages that foreign investor are faced with when investing abroad. In this regard, IFRS is one of the most significant institutional factors in a country that enhances the locational attractiveness of the country or region consistent with the argument of Chen et al. (2014) and Gorden et al. (2012). The paper therefore argues that the type of accounting standards applicable in a country affects its locational attractiveness and hence should result in improvement in Foreign Direct Investment inflows. 


\section{Empirical Literature and Hypothesis Development}

Owusu et al. (2017a) argue that empirical studies examining the relationship between IFRS adoption and its impact on FDI is very limited. The few studies are recent literature focused more on country level studies even though some studies have been done on cross-country level especially in developed economies. The main argument for the adoption of IFRS is to ensure comparability of financial statement by users across borders (Horton, Serafeim, \& Serafeim, 2013) which have been enhanced to include the fact that worldwide adoption of IFRS will facilitate cross-border investment inflows (Tweedie \& Seidenstein, 2005; Bova \& Pereira, 2012). The quality of accounting information in a country is likely to attract foreign direct investment which will propel economic growth. Some empirical studies have examined the subject matter is different context (Owusu et al. 2017a; Owusu et al. 2017b; Amiram, 2012; Beneish et al., 2015; Chen et al., 2014; Gordon et al., 2012; Louis and Urcan, 2014; Márquez-Ramos, 2011; Zhu, 2014). The results of these studies have provided conflicting results. For instance, Owusu et al. (2017a) examined whether developing countries that have adopted IFRS experience higher inflows compared to non-adopting countries. The study sampled 116 countries including those that have adopted and those that are yet to adopt IFRS. The results of the study showed that IFRS adoption alone does not influence FDI inflows. However, countries that have adopted IFRS with good institutional quality experience better FDI inflows. Owusu et al. (2017b) also examined the influence of IFRS adoption on FDI inflows in developing countries. The results showed that there is no influence of IFRS adoption on FDI inflows in developing countries. Márquez-Ramos (2011) used gravity model to examine the influence of IFRS adoption on FDI inflows and found that IFRS adoption has significant influence on FDI inflows among countries that have adopted IFRS. Chen et al. (2014) also adopted the gravity model using IFRS adoption as an institutional infrastructure for location and found that IFRS adoption positively affects FDI inflows. In a similar study, Gordon et al. (2012) examined the influence of IFRS adoption on each country. Okpala, (2012) stated that among countries that have adopted IFRS, uniformity, better interpretation and comparability of financial statements are the implications of the adoption. He also said that global capital markets can be easily accessed by foreign companies, which will enable them to make investments across borders.
Furthermore, companies in Africa will prepare more reliable financial statements as a result of IFRS adoption which will be uniform and comparable with those of international companies and will be easier to interpret. This will definitely boost investor's confidence and attract investments in Africa. Beneish, (2010) findings on the relationship between the IFRS adoption and foreign direct investment as earlier stated is in consonance with the findings of Marques-Ramos (2008) when they found out that IFRS adoption in the European Union has significant impact on attracting foreign direct investment. However, the result of the study is impaired because only four (4) non-EU countries were used as control factors.

Efobi \& Oluwatobi (2014) also examined the relationship between IFRS adoption and the occurrences of global land deals and found that the adoption of IFRS has a positive and significant explanations for the occurrences of global land deals. Adeuja (2015) investigate the impact of IFRS on the performance of banks in Nigeria using a descriptive financial ratios analysis to assess and make comparison on the performance of ten sampled banks covering a four-year period (2010-2013). The result the study revealed no statistical significant difference due to the IFRS adoption. Akpomi. (2017) also investigates the impact of IFRS adoption on FDI and found that the adoption of IFRS has a positive effect on FDIs.

The results of their study showed that IFRS adoption improves FDI inflows in countries that have adopted IFRS as compared to those that have not adopted IFRS. The results of previous studies show conflicting conclusion which call for more studies in the area to establish the real impact of IFRS adoption on FDI inflows. It is also important to note that none of the studies have focused on IFRS only African countries. This study however argues that IFRS adoption by African countries enhances the transparency and institutional quality of that country which boost FDI inflows. The study therefore hypothesizes that;

H1: IFRS adoption has positive and significant impact on FDI inflows in Africa.

\section{Methodology}

The study adopts a quantitative approach as its seeks to establish the relationship between IFRS adoption and FDI inflows in Africa using secondary data. The population of the study includes all countries in Africa which according to the World Bank and IMF 
is 54 countries. The study adopted the purposive sampling technique to sample African countries who have adopted IFRS for financial reporting for their respective country. Based on data from the International Accounting Standard Board, 20 African Countries have adopted IFRS. The sample period covers 1980 to 2015. The sample period was based on the availability of data from the World Bank. Due to unavailability of data on most of the variables for some countries, the study used unbalanced data.

The study used secondary data collected from the World Bank data on macroeconomic variables of countries. The data was specifically sourced from the World Bank World Development Indicators, World Economic Outlook (IMF) and other development agencies. This included data of Foreign DIRECT Investment and other macroeconomic variables. The status of African countries IFRS adoption was sourced from the IFRS foundation website.

\section{Model Specification}

The model adopted for the study is that of Kuznetsova and Muravyev (2001) method for panel regression for objectives. The general form for panel data regression given as:

$$
\mathrm{Y}_{\mathrm{it}}=\alpha+\beta \mathrm{X}_{\mathrm{it}}+\mathrm{e}_{\mathrm{it}} \ldots(1)
$$

Where;

$i=$ the individual cross-sectional dimension (i.e. Countries), and $\mathrm{t}=$ the time dimension (i.e. 19802015).

$\alpha=$ constant/intercept

$\beta=$ the coefficients

$Y_{i t}=$ dependent variables/IFRS adoption and control variables

$X_{i t}=$ the independent variables of the model

$\mathrm{e}_{i t}=$ the residual error of coutry $\mathrm{i}$ at time, $\mathrm{t}$.

From equation (1), we assumed that is the same for all countries, hence we arrive at equation (2) as shown below:

$$
\mathrm{Y}_{\mathrm{it}}=\beta \mathrm{X}_{\mathrm{it}}+\mathrm{e}_{\mathrm{it}} \ldots \text { (2) }
$$

Where the variables are defined as before.

The following regression models was used to determine the impact of IFRS adoption on foreign direct investment as well as the impact of economic growth and an open economy on FDI.

The resulting estimated panel regression model for the study is as follows:

$\mathrm{FDI}_{\mathrm{it}}=\beta_{0}+\beta_{1}$ IFRS dummy $_{\mathrm{it}}+\beta_{2} \mathrm{GDP}_{\mathrm{it}}+\beta_{3} \mathrm{OPEN}_{\mathrm{it}}+$ $\beta_{4}$ GOVDEBT $_{\text {it }}+\beta_{5}$ POPGROWTH $_{\text {it }}+\varepsilon_{\text {it }}$

Where;

FDI : Foreign direct investment as a percentage of GDP

IFRS : Dummy, 1 if a country has adopted IFRS, 0 otherwise

GPD : Economic growth measured as Real GDP growth rate

OPEN : (Sum of exports and imports) as a percentage of GDP

GOVDEBT : Gross government debt as a percentage of GDP (as a proxy for public debt)

POPGROWTH : Population growth in percentage

\section{Analysis and Discussion}

\section{Descriptive Analysis}

This section of the study presents a brief description of the variables used for the study using simple characteristics such as their means, standard deviation, minimum values and maximum value. Table 1 Present a summary of the descriptive analysis of the variables used for the study.

Table 1

Descriptive Statistics

\begin{tabular}{llrrr}
\hline Variable & Mean & Std. Dev. & \multicolumn{1}{c}{ Min } & \multicolumn{2}{c}{ Max } \\
\hline FDI & 2.740084 & 1.172583 & -28.62 & 41.81 \\
IFRS & 0.273717 & 0.4462125 & 0 & 1 \\
DUMMY & 4.466353 & 5.941194 & -50.25 & 35.22 \\
GDP & 57.79111 & 43.7571 & 5 & 245 \\
GOVDEBT & 68.96779 & 39.95163 & 8.95 & 211 \\
OPEN & 2.473299 & 1.172583 & -6.185 & 7.918 \\
POPGROWTH
\end{tabular}


The results from table 1 show that the average FDI inflow as a percentage of GDP over the study period is $2.7 \%$ with a maximum of $42 \%$. The average FDI as a percentage of GDP rate is lower than that reported by Owusu et al. (2017) based on a sample of developing countries where the average FDI as a percentage of GDP was $4.78 \%$ and a maximum of $83 \%$. The results suggest that FDI inflows into Africa are generally lower compared with other developing countries in other continents.

The second variable which if IFRS adoption showed an average of $27 \%$ suggesting that on average the sample observation had $27 \%$ of the period being years where IFRS was adopted and the remaining otherwise. This is relatively higher than the $23 \%$ reported by Owusu et al. (2017).

The next variable measured GDP growth rate over the study period. The results show that the average GDP growth over the study period is $4.5 \%$

The descriptive statistics also shows that the average government debt as a percentage of GDP is $58 \%$ which is lower that the high risk category of $70 \%$ based on the World Bank and IMF classification.

The next variable measured the extent to which a country is open which is based on their imports and exports. The results show that imports and exports as a percentage of GDP is averaged $68 \%$ over the study period. The result is similar to the findings of Owusu et al. (2017) whose study reported an average of $63 \%$. The results show that the sample of countries has relatively open economy which is expected to influence FDI inflows.

Finally, the average population growth rate over the study period is $2.47 \%$. This rate of population growth is relatively higher compared to studies on developed economies. The results confirm the general assertion that population growth in Africa is generally higher compared to other continents especially developed economies. The higher population growth rate has the potential to create a bigger market in Africa that will attract FDI. This is the reason why; previous studies see population growth as a potential predictor of FDI inflows.

\section{Correlation Analysis}

This section presents Pearson analysis of the variables to establish the relationship that exists between the dependent variable (FDI) and the independent variables (IFRSDUMMY, GDP and OPEN) and the control variables (GOVDEBT and POPGROWTH). The results of the correlation analysis are presented in table 2 .

Table 2

Correlation Results of FDI and other independent variables

\begin{tabular}{lcccccc}
\hline & FDI & IFRS & GDP & OPEN & GOVDEBT & POPGROWTH \\
\hline FDI & 1.00 & & & & \\
IFRSDUMMY & $0.2673^{* * * *}$ & 1.00 & & & & \\
GDP & $0.1365^{* * * *}$ & 0.1067 & 1.00 & & & \\
OPEN & $0.2963 * * *$ & 0.1375 & 0.1452 & 1.00 & \\
GOVDEBT & 0.0297 & -0.234 & -0.1092 & -0.212 & 1.00 & \\
POPGROWTH & 0.0501 & -0.1122 & 0.2344 & -0.2566 & 0.0175 & 1.00 \\
\hline *** Significant at $1 \%, * *$ Significant at $5 \%, *$ significant at $10 \%$ &
\end{tabular}

The result from the correlation analysis shows that there is a positive and significant correlation between IFRS adoption and FDI inflows in Africa. The results suggest that African countries that have adopted IFRS have improved their FDI inflows which are consistent with the perceived benefits of adopting IFRS in any country. The result is consistent with the findings of Owusu et al. (2017) and Emeni (2014) who all found a positive correlation between IFRS adoption and FDI inflows.

The study also showed that there is a positive and significant correlation between GDP growth and FDI inflows. The result shows that countries that have high economic growth rate or growth potentials are likely to attract more FDI compared to those with low growth rate.

The correlation analysis also shows that there is a positive correlation between open economy and foreign direct investment inflows. The results suggest that countries more imports and exports attract more FDI inflows compared to countries with closer economies in terms of imports and exports. The result is consistent with the expectations of the study and also consistent with the results of previous studies. The results suggest that African countries can improve FDI inflows through improving imports and export.

On the control variable, both population and government debt were positively correlated with FDI inflows even though there were statistically 
insignificant. In other words, there was a weak correlation between FDI inflows and population growth as well as with government debt.

\section{Regression Analysis}

The third statistical tool used was the panel regression model. Before conducting the regression results, the study first conducted a multicollinearity test using the correlation result based on the rule of thumb and the Variance Inflation Factor. Both results show little evidence of multicollinearity. The study adopted the General Least Square panel regression model in stata based on the random effect after conducting the Haussmann test. The results of the panel regression analysis which answers the main objectives of the study is presented in table 3 below.

Table 4

Regression Results between FDI and other independent variables

\begin{tabular}{lrrr}
\hline Variable & Coefficient & Std. Err. & $\mathrm{Z}$ \\
\hline IFRS & $2.905208 * * *$ & 0.4226999 & 6.87 \\
GDP & -0.0115461 & 0.0359858 & -0.32 \\
OPEN & $0.0722649 * * *$ & 0.00779913 & 9.04 \\
GOVDEBT & $0.0096521 * *$ & 0.0047285 & 2.04 \\
POPGROWTH & $0.3505903 * *$ & 0.1784424 & 1.96 \\
CONS & -4.274766 & 0.9907095 & -4.31 \\
Wald Chi2(6) & 156.66 & & \\
Prob>Chi2 & 0.000 & & \\
R-Square & 0.2444 & \\
*** Significant at 1\%, * Significant at 5\%, significant at $10 \%$
\end{tabular}

The regression results show that the R-square is $24 \%$ suggesting that the independent variables can explain only $24 \%$ of the variation in the dependent variable (FDI inflows). However, the result of the Wald Chi2 is statistically significant suggesting that the model is well fit. The lower R-square for the study is not surprising as most previous studies on the subject matter or similar studies have reported lower R-Square. For instance, Emeni (2014) reported an Rsquare of $10.45 \%$. Owusu et al. (2017) in their study reported and R-Square of $26 \%$.

On the main variable of focus, the regression result confirms the findings of the correlation analysis and shows that there is a positive association between IFRS adoption and FDI inflows. The relationship is statistically significant at $1 \%$ significance level. The result shows that countries that adopt IFRS in Africa will record improved inflows in FDI. The results have significant implication for other African countries that are yet to adopt IFRS as they seek to improve FDI inflows into their country. The result is consistent with the first hypothesis of the study which predicted a positive association between IFSR adoption and FDI inflows. The result is also consistent with the findings of several studies in both developed and developing countries.

On the second variable in the model, economic growth (GDP), the results show a negative association between economic growth and FDI inflows even though the relationship is statistically insignificant. The results suggest that improvements in a country's economic growth rate do not translate directly into improvement in FDI inflows. The result is inconsistent with the expectation of the second hypothesis of the study which predicted a positive and significant association between economic growth and FDI growth. The result appears inconsistent with several previous studies on the subject matter. The result suggests that countries with higher economic growth need to provide enabling environment to attract FDI and not rely on their high growth potential alone.

The next independent variable of interest is open economy and FDI growth in Africa. The result from the regression analysis shows a positive and significant association between an open economy and FDI growth. The relationship is statistically significant at $1 \%$ significance level. The result is consistent with the expectations of the second hypothesis of the study which predicts a positive and significant association between an open economy and FDI growth. The result confirms the assertion that countries that have more liberal and open market for both imports and exports are able to attract Foreign Direct Investment and vice versa. The results suggest that African countries must improve their imports and export to attract more FDI into their respective countries.

On the control variables, the regression results revealed a positive relationship between government debt and FDI growth in Africa. The relationship between the two variables is statistically significant at $5 \%$ significance level. The results suggest that high government debt to GDP ratio encourages more FDI inflows contrary to the expectation that high debt will increase risk profile of the country and reduce FDI growth. The result has some significant implications for most African countries as debt management is a greater concern for African countries. However, it can be deduced that the positive association between government debt to GDP ratio and FDI growth could as a result of the fact that government most public debt 
in Africa are used for infrastructure development which enhances the competitiveness of the country's business sector. Moreover, the borrowing of government from international capital markets in the form of Eurobonds could be a source of FDI inflows.

The last control variable population growth (POPGROWTH) also revealed a positive and significant association with FDI growth in Africa. The relationship was statistically significant at $5 \%$ significance level. The result shows that African countries with high population growth potential attract more FDI compared to countries with low population growth. The results confirm the assertion that population growth have significant influence on the purchasing power of people in an economy and as such an opportunity for doing business in such countries. The result also shows that Africa's high population growth rate have some economic benefits that should not be underestimated.

\section{Discussion of findings}

The main objective of the study is to examine the impact of IFRS adoption on FDI growth in Africa. The result from the study shows that IFRS adoption in Africa improves FDI growth in Africa. The result is consistent with the hypothesis of the study and also consistent with several studies in literature. The result is consistent with the findings of Gordon et al. (2012) whose study also reported a positive association between IFRS adoption and FDI inflows. The result is also consistent with the findings of Chen et al. (2014) where they found a positive and significant association between IFRS adoption and FDI inflows. In a similar study Marquez-Ramos (2011) also found a positive association between IFRS adoption and FDI inflows. Some few studies reported an insignificant association between IFRS adoption and FDI inflows or growth. For instance, the study by Owusu et al. (2017) found a positive but statistically insignificant association between IFRS adoption and FDI growth among a sample of developing countries across the globe. In a similar study, Emeni (2014) found a positive but statistically insignificant association between IFRS adoption and FDI inflows based on a sample of some African countries that have either adopted IFRS or are yet to adopt IFRS. The result shows that adopting IFRS opens up a country's economy to attract more FDI as envisaged by the proponents of IFRS.

The results of the regression analysis found that GDP growth rate was positively associated with FDI inflows even though the relationship was statistically insignificant. The result shows that economic growth contributes in a way towards FDI inflows which is consistent with the findings of several studies. For instance, Mottaleb \& Kalirajan (2010) in their study of determinants of FDI inflows in developing countries found that the countries with high GDP growth rate experienced high inflows of FDI. GDP growth is considered a key variable to explain variation in FDI - foreign investors are likely to consider the target country's income, output and production capacity. These factors will unduly affect market size. The findings that GDP and its growth rate positively affect the inflow of FDI to developing countries supports the findings by Nunnenkamp \& Spatz (2002), Torrisi (1985), Schneider and Frey (1985), and Jun and Singh (1996). Similar to the findings of Daude \& Stein (2007) and Disdier and Mayer (2004), our study also confirms the fact that the business environment in the developing countries the proxy of which was the days required to start a business, significantly affect the inflow of FDI to developing countries. Importantly, our study clearly shows that foreign aid significantly and positively affects inflow of FDI to developing countries and the finding is robust. The finding supports the finding of Kimura \& Todo (2010) who using disaggregated data show that Japanese aid enhances FDI inflow to the aid receiving countries.

The results also revealed that the proportion of export and import as a percentage of GDP is positively associated with FDI inflows. The result is consistent with the expectation of the study which suggested a positive association between open economy and FDI growth. Business friendly environment with appropriate rules and regulations might significantly reduce the operation and hidden cost and allows market to function well. Thus, profit seeking foreign investors might prefer to invest in countries where there is business friendly environment and the rules and regulations relating to investment and business are favorable. Socio-economic and socio-politico variables, such as regulatory framework, bureaucratic hurdles and red tape, regulations relating to initiate a new business, judicial transparency, and the extent of corruption in the host country therefore might significantly affect the inflow of FDI by affecting the efficiency, productivity and cost structure.

The results also found population growth and government debt to GDP to be significant predictors of FDI growth in Africa.

\section{Conclusion}

The study examined macroeconomic implication of IFRS adoption in Africa. Specifically, the study 
examined how IFRS adoption affects FDI inflows among African countries that have adopted IFRS. The study however included other variables such as economic growth, open economy etc which have been found to be potential determinants of FDI inflows.

The analysis has at least three very important features, Firs, it is among the few if not the first, to analyze the significant impact of IFRS on FDI in Africa. Secondly, to determine the effect of an open economy on FDI inflow and lastly, to determine the effect of economic growth on FDI inflow. It therefore relies on a much stronger identification instrument than prior studies, which enables us to more reliably establish a causal relation between IFRS and the shift in foreign investments around the mandatory IFRS adoption.

On the main variable of focus, the regression result confirms the findings of the correlation analysis showed that there is a positive association between IFRS adoption and FDI inflows. The relationship is statistically significant which shows that countries that adopt IFRS in Africa will record improved inflows in FDI. Secondly, the variable in the model, economic growth (GDP), and the results showed a negative association between economic growth and FDI inflows even though the relationship is statistically insignificant. The result suggested that improvements in a country's economic growth rate do not translate directly into improvement in FDI inflows. The independent variable of interest is open economy and FDI growth in Africa. The result from the regression analysis showed a positive and significant association between an open economy and FDI growth. The result confirms the assertion that countries that have more liberal and open market for both imports and exports are able to attract Foreign Direct Investment and vice versa.

\section{References}

Adeuja, Y. O. (2015). A Comparative Approach to the Impact of IFRS (International Financial Reporting Standards) on the Performance of Banks in Nigeria (Doctoral dissertation, Eastern Mediterranean University (EMU)-Doğu Akdeniz Üniversitesi (DAÜ)).

Ahearne, A. G., Griever, W. L., \& Warnock, F. E. (2004). Information costs and home bias: an analysis of US holdings of foreign equities. Journal of international economics, 62(2), 313336.

Ahmed, A. S., Neel, M., \& Wang, D. (2013). Does mandatory adoption of IFRS improve accounting quality? Preliminary evidence. Contemporary Accounting Research, 30(4), 1344-1372.
Akpomi, M. E., \& Nnadi, M. A. (2017). The impact of International Financial Reporting Standards (IFRS) adoption on Foreign Direct Investments (FDI): Evidence from Africa and implications for managers of education.

Amiram, D. (2012). Financial information globalization and foreign investment decisions. Journal of International Accounting Research, 11(2), 57-81.

Asiedu, E. (2006). Foreign direct investment in Africa: The role of natural resources, market size, government policy, institutions and political instability. World economy, 29(1), 63-77.

Barth, M. E., Landsman, W. R., \& Lang, M. H. (2008). International accounting standards and accounting quality. Journal of accounting research, 46(3), 467-498.

Beneish, M. D., Miller, B. P., \& Yohn, T. L. (2015). Macroeconomic evidence on the impact of mandatory IFRS adoption on equity and debt markets. Journal of Accounting and Public Policy, 34(1), 1-27.

Bova, F., \& Pereira, R. (2012). The determinants and consequences of heterogeneous IFRS compliance levels following mandatory IFRS adoption: Evidence from a developing country. Journal of International Accounting Research, 11(1), 83-111.

Buckley, P.J., and M.C. Casson. 1976. The future of multinational enterprises. London: Macmillan

Busse, M., \& Hefeker, C. (2007). Political risk, institutions and foreign direct investment. European journal of political economy, 23(2), 397-415.

Chakrabarti, A. (2007, February). Determinants of FDI: A comment on globalization-induced changes and the role of FDI policies. In Annual Bank Conference on Development Economics (ABCDE), World Bank, June, Oslo, Norway. http://wbln0018. worldbank. org/eurvp/web.

nsf/7cbe87578041c85ac12569e4003998b2/c7fad1de6e5d49a9c12 56bea0046cce3/\$ FILE/Chakrabarti. pdf. Accessed (Vol. 20).

Chen, C. J., Ding, Y., \& Xu, B. (2014). Convergence of accounting standards and foreign direct investment. The International Journal of Accounting, 49(1), 53-86.

Chen, C., Young, D., \& Zhuang, Z. (2012). Externalities of mandatory IFRS adoption: Evidence from cross-border spillover effects of financial information on investment efficiency. The Accounting Review, 88(3), 881-914.

Coase, R. H. (1937). The nature of the firm. economica, 4(16), 386405.

Daske, H. (2006). Economic Benefits of Adopting IFRS or USGAAP-Have the Expected Cost of Equity Capital Really Decreased?. Journal of Business Finance \& Accounting, 33(3-4), 329-373.

Disdier, A. C., \& Mayer, T. (2004). How different is Eastern Europe? Structure and determinants of location choices by French firms in Eastern and Western Europe. Journal of comparative Economics, 32(2), 280-296.

Dunning, J. H. (1979). Explaining changing patterns of international production: in defence of the eclectic theory. Oxford bulletin of economics and statistics, 41(4), 269-295.

Efobi, U., \& Oluwatobi, S. (2014). The Geographic Implication of IFRS Adoption. Available at 
SSRN: https://ssrn.com/abstract=2476965 or http://dx.doi.org/10.2 139/ssrn.2476965

Emeni, F. K. (2014). Foreign direct investments and international financial reporting standards adoption in Africa. Ushus Journal Business Management, 27-44.

Forssbæck, J., \& Oxelheim, L. (2008). Finance-specific factors as drivers of cross-border investment-An empirical investigation. International Business Review, 17(6), 630-641.

Frenkel, M., Funke, K., \& Stadtmann, G. (2004). A panel analysis of bilateral FDI flows to emerging economies. Economic systems, 28(3), 281-300.

Gordon, L. A., Loeb, M. P., \& Zhu, W. (2012). The impact of IFRS adoption on foreign direct investment. Journal of Accounting and Public Policy, 31(4), 374-398.

Horton, J., Serafeim, G., \& Serafeim, I. (2013). Does mandatory IFRS adoption improve the information environment?. Contemporary accounting research, 30(1), 388-423.

Hymer, S. (1970). The efficiency (contradictions) of multinational corporations. The American Economic Review, 60(2), 441-448.

Ismail A, W., Anuar Kamarudin, K., van Zijl, T., \& Dunstan, K. (2013). Earnings quality and the adoption of IFRS-based accounting standards: Evidence from an emerging market. Asian Review of Accounting, 21(1), 53-73.

Kimura, H., \& Todo, Y. (2010). Is foreign aid a vanguard of foreign direct investment? A gravity-equation approach. World Development, 38(4), 482-497.

Kuznetsov, P., \& Muravyev, A. (2001). Ownership concentration and firm performance in Russia: the case of blue chips of the stock market. Acta Oeconomica, 51(4), 469-488.

Louis, H., \& Urcan, O. (2014). The effect of IFRS on cross-border acquisitions. Working paper

Márquez-Ramos, L. (2011). European accounting harmonization:
Consequences of IFRS adoption on trade in goods and foreign direct investments. Emerging markets finance and trade, 47(sup4), 42-57.

Mottaleb, K. A., \& Kalirajan, K. (2010). Determinants of foreign direct investment in developing countries: A comparative analysis. Margin: The Journal of Applied Economic Research, 4(4), 369-404.

Nunnenkamp, P., \& Spatz, J. (2004). FDI and economic growth in developing economies: how relevant are host-economy and industry characteristics. Transnational corporations, 13(3), 53-86.

Okpala, K. E. (2012). Adoption of IFRS and financial statements effects: The perceived implications on FDI and Nigeria economy. Australian Journal of Business and Management Research, 2(5), 76.

Owusu, G. M., Saat, N. A. M., Suppiah, S. D. K., \& Siong, H. L. (2017). IFRS Adoption, Institutional Quality and Foreign Direct Investment Inflows: A Dynamic Panel Analysis. Asian Journal of Business and Accounting, 10(2), 43-75.

Owusu, G., Yaw, M., Saat, N. A. M., Suppiah, S. D., \& Hook, L. S. (2017a). Do Accounting Standards Matter for Foreign Direct Investment in Developing Countries?. International Journal of Economics \& Management, 11.

Ramanna, K., \& Sletten, E. (2009). Why do countries adopt international financial reporting standards?. Working paper. Harvard Business School.

Teece, D. J. (1986). Transactions cost economics and the multinational enterprise An Assessment. Journal of Economic Behavior \& Organization, 7(1), 21-45.

Tweedie, D., \& Seidenstein, T. R. (2004). Setting a global standard: The case for accounting convergence. Nw. J. Int'l L. \& Bus., 25 , 589.

Zhu, W. (2014). The evolving economic role of accounting standards: Evidence from bilateral cross-border M\&A flows. Frontiers of Business Research in China, 8(4), 435-479. 